\title{
Hots based learning strategy on Modern Sanggul courses
}

\author{
Trisnani Widowati ${ }^{1}$ \\ \{niwid272@gmail.com ${ }^{1}$ \} \\ Home Economic, Universitas Negeri Semarang ${ }^{1}$
}

\begin{abstract}
Modern bun is a course that teaches different kinds of bun arrangement for various occasions. The study aims to describe the implementation of hots-based learning strategies on modern bun courses on the cognitive, affective and psychomotor aspects of the School of Beauty studies Program. This study was conducted at PKK Department of Beauty Education study Program, Faculty of Engineering UNNES. The population in this study is a 4th semester beauty student with a total sampling of 24 students. Data collection instruments consist of poll, assessment and problem sheet. Data analysis is done by using descriptive percentages. The results show that students have a category of learning outcomes: 1) Cognitive aspects to pretests the category is $83.3 \%$, low category $16.5 \%$, for posttest category is $67.5 \%$, low category $32.5 \%, 2$ ) affective aspect, the results of the category pretests is $62.5 \%$, low category $37.5 \%$, for posttest categories are $41.67 \%$, low category $58.33 \%$ and 3 ) Psychomotor aspects, high category pretests results $29.17 \%$, category medium $54.17 \%$, low category $16.67 \%$ and Results posttest High category $20.83 \%$, category medium $37.5 \%$, low category $41.67 \%$. The overall results of this decline are due to the need to continuously implement the Hots learning strategy so that students can perform analyses that can bring out the creativity of creation.
\end{abstract}

Keywords: Hots learning strategy, modern Bun Setup

\section{Introduction}

In the learning process, a teacher is required to develop the optimum potential of learners. Teachers as implementers in the learning process must have an understanding of the learning strategies used to encourage the development of learners ' potential.

The use of strategy in learning will make it easy for teachers to achieve their learning objectives effectively and efficiently. Learning strategy is an activity to seek and utilize a variety of learning resources that are owned in learning to achieve competence or learning objectives. In addition, learning strategy is the guideline and reference to act systematically in learning for a teacher, while for students, the strategy that is done by the teacher can facilitate the learning process.

The strategies that can be used include integrating the higher order Thinking Skills (HOTS) in the learning process. Higher Order of Thinking Skill (HOTS) or high-level thinking skills are an ability to think that requires not only the ability to remember, but requires other higher abilities, such as creative and critical thinking skills. This is in line with the demands of the 21 st century competence which is criticial thinking, creative and innovative, communication skills, ability to cooperate (collaboration) and confidence (Ditjen GTK: 2018:2). 
One of the strategies that can be used to develop HOTS is to implement an active learning model centered on learners and based on Constructivism. A learning model based on constructivism that can help learners to develop the ability to analyze, evaluate, and create is a learning model of Problem Based Learning. The LBL is a learning model that emphasizes authentic problem-solving such as problems occurring in everyday life (Tung, 2015:228). It is in accordance with the opinions of Kilbane \& Milman (2014:281), the problem-based learning model is an active learning model that allows students to learn and hone problem-solving skills, develop competence with academic content standards, and realize the relevance of applying content area learning for practical purposes. The Problem-Based Learning model consists of four major phases or steps: (1) present or identify the problem, (2) develop a plan for solving the problem, (3) Implement the plan for solving the problem, and (4) Evaluate the implementation plan results.

The implementation of this learning strategy in modern bun courses is one of the efforts to create independent students and to improve their creativity through the ability to analyse and evaluate their work. Modern bun learning is usually done through demonstration methods and students do in accordance with the examples given, this makes the lack of independence and creativity of students especially in the process of creating a bun that is adapted to the shape of the face. Therefore, the need to familiarize students to think critically and creatively in order to be able to apply their skills in community life. This strategy is suitable for modern bun learning because students must have the ability to analyze various facial forms, determine the form of a bun, use the ability to communicate and cooperate with the model in the application of its knowledge.

Based on this, it is necessary to know how the results of the implementation of HOTSbased learning strategy (problem based learning) in modern bun learning.

\section{Research objectives}

This research aims to describe the results of implementing HOTS-based learning strategy in the learning of modern bun based on cognitive, affective and psychomotor aspects.

\section{Research Methods}

This research refers to quantitative research approaches. While the type of research used in this research is research quasi experimental design. The population in this study is a student of the beauty study program of PKK faculty of Engineering Unnes who took the course of modern bun semester 4 a number of 24 people. Sampling technique uses a total sampling. The method of collecting data on this research is derived from the documentation that contains the results of a bun arrangement based on the face form seen from cognitive, affective and psychomotor aspects. The analytical techniques used in this research are descriptive analysis with a quantitative approach. A descriptive analytical technique used to demonstrate the extent to which the achievement of learning outcomes by implementing Hots-Based Learning Strategies (PBL) is based on cognitive, affective and psychomotor aspects. 
Table 1. Category sharing assessment of learning outcomes

\begin{tabular}{|l|l|c|}
\hline \multicolumn{1}{|c|}{ Category } & \multicolumn{1}{c|}{ Score } & Scale \\
\hline High & $X<(\mu-1,0 \sigma)$ & \multirow{2}{*}{ Ordinal } \\
\hline medium & $(\mu-1,0 \sigma) \leq X<(\mu+1,0 \sigma)$ & \\
\hline low & $X \geq(\mu+1,0 \sigma)$ & \\
\hline
\end{tabular}

\section{Results and discussion}

The results of a descriptive analysis of the cognitive aspects before and after the implementation of Hots-based Learning Strategy (PBL) with the achievement category of high, moderate, and low .

Table 2. Cognitive Pretest Results

\begin{tabular}{lllll}
\hline category & Frequency & Percent & $\begin{array}{l}\text { Valid } \\
\text { Percent }\end{array}$ & $\begin{array}{l}\text { Cumulative } \\
\text { Percent }\end{array}$ \\
\hline Medium & 20 & 83.3 & 83.3 & 83.3 \\
\hline Low & 4 & 16.5 & 16.5 & 100.0 \\
\hline Total & 24 & 100.0 & 100.0 & \\
\hline
\end{tabular}

Table 3. Cognitive Posttest Results

\begin{tabular}{lllll}
\hline category & Frequency & Percent & $\begin{array}{l}\text { Valid } \\
\text { Percent }\end{array}$ & $\begin{array}{l}\text { Cumulative } \\
\text { Percent }\end{array}$ \\
\hline Medium & 11 & 67.5 & 67.5 & 67.5 \\
\hline Low & 13 & 32.5 & 32.5 & 100.0 \\
\hline Total & 24 & 100.0 & 100.0 & \\
\hline
\end{tabular}

Based on table 2 results pretests and table 3 results posttest of the entire respondent can be known there is a number of students in the category of medium to cognitive aspects. The pretests results showed a number of 20 students $(83.3 \%)$ is in the category of medium and after getting the treatment occurs a decline of 11 mahasisiwa (67.5\%) Medium category. There is a decline in the number of students in medium category. This is because students are less concerned with theoretical mastery, more focused on practice and are not yet accustomed to analyze deeply on hairdressing for various facial forms because they usually practice using mannequin and pay attention to the lecturer demonstration.

Table 4. Affective Pretest Results

\begin{tabular}{lllll} 
Category & Frequency & Percent & $\begin{array}{l}\text { Valid } \\
\text { Percent }\end{array}$ & $\begin{array}{l}\text { Cumulative } \\
\text { Percent }\end{array}$ \\
\hline Medium & 15 & 62.5 & 62.5 & 62.5 \\
\hline Low & 9 & 37.5 & 37.5 & 100.0 \\
\hline Total & 24 & 100.0 & 100.0 & \\
\hline
\end{tabular}


Table 5. Affective Posttest Results

\begin{tabular}{lllll}
\hline Category & Frequency & Percent & $\begin{array}{l}\text { Valid } \\
\text { Percent }\end{array}$ & $\begin{array}{l}\text { Cumulative } \\
\text { Percent }\end{array}$ \\
\hline Medium & 10 & 41.67 & 41.67 & 41.67 \\
\hline Low & 14 & 58.33 & 58.33 & 100 \\
\hline Total & 24 & 100.0 & 100.0 & \\
\hline
\end{tabular}

Based on table 4 on the affective aspect of the pretests results shows a category of 15 students $(62.5 \%)$, low category $9(37.5 \%)$ and table 5 results of posttest are known to decrease the number of students in the category as much as 10 students $(41.67 \%)$ and low $14(58.33 \%)$

Table 6. Psychomotor Pretest Results

\begin{tabular}{lllll} 
Category & Frequency & Percent & $\begin{array}{l}\text { Valid } \\
\text { Percent }\end{array}$ & $\begin{array}{l}\text { Cumulative } \\
\text { Percent }\end{array}$ \\
\hline High & 7 & 29.17 & 29.17 & 29.17 \\
\hline Medium & 13 & 54.17 & 54.17 & 54.17 \\
\hline Low & 4 & 16.67 & 16.67 & 100.0 \\
\hline Total & 24 & 100.0 & 100.0 & \\
\hline
\end{tabular}

Table 7. Psychomotor Posttest Results

\begin{tabular}{lllll}
\hline Kategori & Frequency & Percent & $\begin{array}{l}\text { Valid } \\
\text { Percent }\end{array}$ & $\begin{array}{l}\text { Cumulative } \\
\text { Percent }\end{array}$ \\
\hline High & 5 & 20.83 & 20.83 & 20.83 \\
\hline Medium & 9 & 37.5 & 37.5 & 37.5 \\
\hline Low & 10 & 41.67 & 41.67 & 100.0 \\
\hline Total & 24 & 100 & 100.0 & \\
\hline
\end{tabular}

Based on table 6 pretests results on the psychomotor aspect known number of students in the high category of 7 students (29.17\%), category is 13 students $(54.17 \%)$ and a low category of 4 (16.67\%). After implementation of the Hots Learning Strategy (PBL) (table. 7) There was a decline in the number of students in the high category of 5 students $(20.83 \%), 9$ students $(37.5 \%)$ Category medium, and Low category $10(41.67 \%)$. Decreasing the amount after postest because students find it difficult to apply the concept of the arrangement because of different hair conditions, in the daily practice of using mannequin with an ideal face is on a problem based students are asked to make a bun arrangement with a real model (human). Need habituation to practice directly with different models of face shape. 

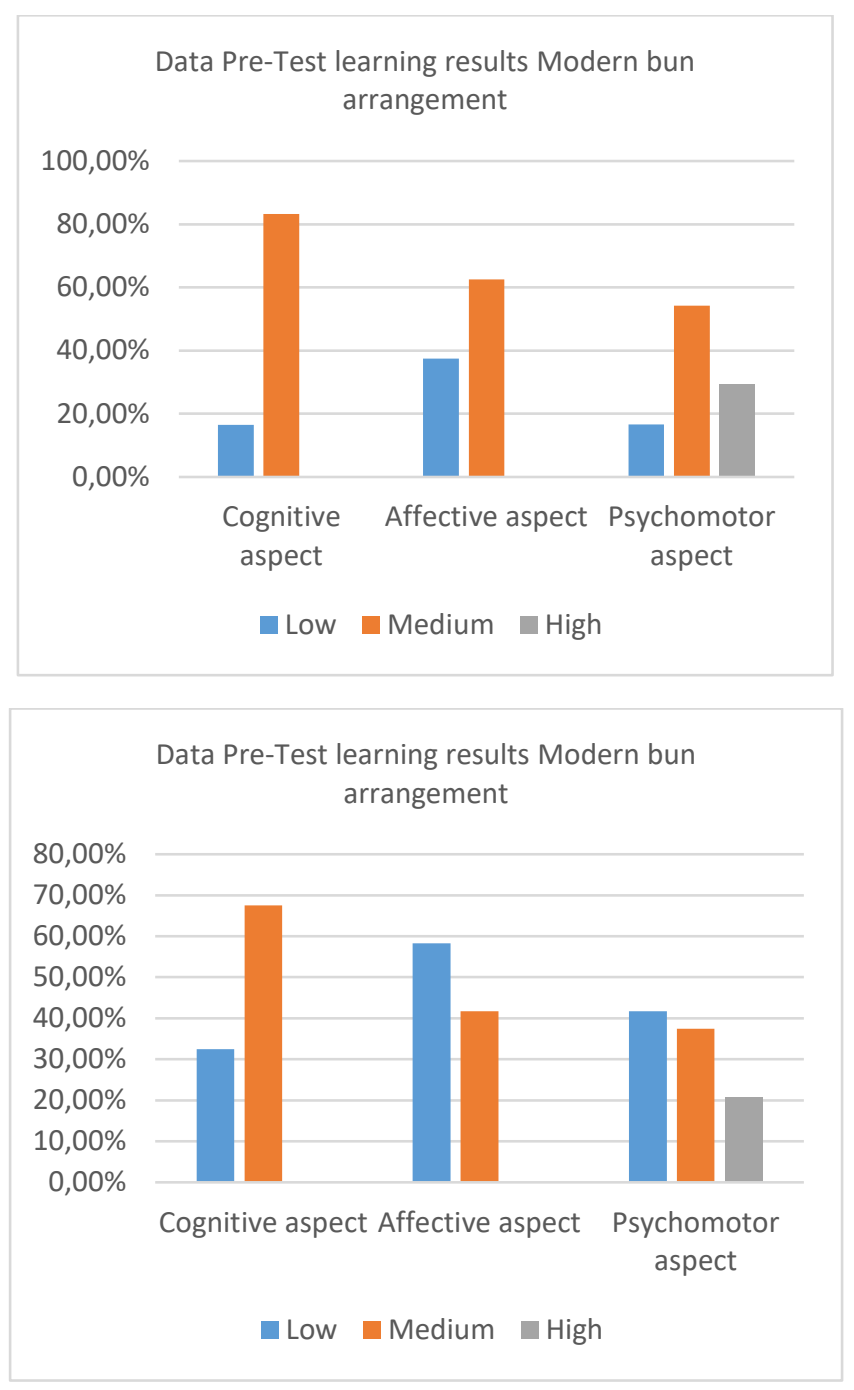

\section{Conclusion}

Based on the results of the analysis shows the decline of results based on cognitive, affective and psychomotor aspects in the study of making modern bun according to facial form using Hots-based learning Strategy (PBL). This is because students are less concerned with the mastery in theory, more focused on practice and yet accustomed to analyze deeply on the styling of the hair for various forms of the face because it usually pays attention to the demonstrations given by the lecturer. In addition, students find it difficult to apply the concept of the arrangement because of different hair conditions, in daily exercises using mannequin with the ideal face and the implementation of its design with the real model (human). Therefore, the need for habituation to conduct analysis on various forms of face and practice directly with the real model so that it can familiarize students with creative and critical thinking. 


\section{References}

[1] Ariyana,Yoki, Pudjiastuti Ari, Bestary Reisky \& Zamroni, 2018. Buku Pegangan Pembelajaran Berorientasi pada Keterampilan Berpikir Tingkat Tinggi .Direktorat Jenderal Guru dan Tenaga Kependidikan Kementerian Pendidikan dan Kebudayaan.

[2] Burden. Paul R, David M. Byrd. 2013. Methods for Effective Teaching Meeting the Needs of All Students.USA: Pearson Education,Inc.

[3] Clare R.Kilbane \& Natalie B Milman , 2014. Teaching models designing instruction for 21st century learners. Pearson education,Inc USA

[4] Cruickshank.Donald R,Deborah Bainer Jenkins, Kim K.Metcalf.2006. Te Act of Teaching. New York: McGraw-Hill

[5] Elaine.H.J.Yewa and Karen Gohb Health Professions Education 2 (2016) 75-79, Problem-Based Learning: An Over view of its Process and Impact on Learning.

[6] FarahnazMovahedzadeh, Ryan Patwell, Jenna E. Rieker, and Trinidad Gonzalez. Hindawi Publishing Corporation Education Research International Volume 2012, Article ID 536024, 8 pages. Project-Based Learning to Promote Effective Learning in Biotechnology Courses

[7] Health Professions Education 3 2017) 26-31.What We Think We Know About the Tutorin Problem-Based Learning. Judith C.Williams,DeborahJ.Paltridge

[8] Khoe Yao Tung.2015. Pembelajaran dan Perkembangan Belajar. Jakarta: PT. Indeks

[9] Kasetsart Journal of Social Sciences 38 (2017) 297- 306, Development of a problem-based learning model via a virtual learning environment

[10] Nancy W. Gleason ,2018. Higher Education in the Era of the Fourth Industrial Revolution. Palgrave Macmillan Singapore.

[11] Newby, Timothy.J, Donald.A.Stepich, James. D. Lehman \& James. D. Russell.2000. Instructional Technology for Teaching and Learning. New Jersey: Prentice Hall,Inc.

[12] Ronghuai Huang, J. Michael Spector Junfeng Yang,2019. Educational Technology A Primer for the 21st Century. SPRINGER nature singapore Pte,Ltd

[13] Rusman.2012. Belajar dan Pembelajaran Berbasis Komputer Mengembangkan Profesionalisme GuruAbad 21. Penerbit: Alfabeta. Bandung.

[14] Rojana Phungsuk, Chantana Viriyavejakul, Thanin Ratanaolarn. Kasetsart Journal of Social Sciences 38 (2017) 297-306, Development of a problem-based learning model via a virtual learning environment

[15]South African Journal of Education; 2014; 34(1). The effects of problem-based learning on preservice teachers' critical thinking dispositions and perceptions of problem-solving ability.Senar Temel 